\title{
Evaluation of Antioxidant Activities and Estimation of Zinc Content of Aqueous and Methanolic Extracts of Three Medicinal Plants: Cochlospermum Planchonii, Pericopsis Laxiflora and Harungana Madagascariensis
}

\author{
Koffi A. Jeanne ${ }^{1, *}$, Bla K. Brice ${ }^{1}$, Silué K. Dieudonné ${ }^{2}$ Tuo Karim³ ${ }^{3}$, Yapi H. Félix ${ }^{1}$ \\ ${ }^{1}$ Laboratory of Biochemical-Pharmacodynamics, Felix Houphouet Boigny University, Cote d'Ivoire \\ ${ }^{2}$ Environment and Health Department, Swiss Centre for Scientific Research, Cote d'Ivoire \\ ${ }^{3}$ Department of Parasitology, Institut Pasteur de Cote d'Ivoire, Cote d'Ivoire
}

Copyright $\bigcirc 2016$ by authors, all rights reserved. Authors agree that this article remains permanently open access under the terms of the Creative Commons Attribution License 4.0 International License

\begin{abstract}
Malaria disease is a pathology which occurs as a result of the oxidative stress. Three plants of the Ivorian pharmacopoeia are particularly used in the traditional medicine for the treatment of malaria in Côte d'Ivoire. They are Cochlospermum planchonii (Placo), Pericopsis laxiflora (Laper) and Harungana madagascariensis (Madhar).The objective of this study was to evaluate the in vitro antioxidant activity of the aqueous and methanolic extracts of three medicinal plants of Côte d'Ivoire. The quantitative measurement of total flavonoids gave the following results: Laper $(560.80 \mathrm{mg} \mathrm{QE} / \mathrm{g} \pm 7.40)$, Madhar (352.50 mg QE/g \pm 9.46) and Placo (314.20 mg $\mathrm{QE} / \mathrm{g} \pm$ 4.41). The total polyphenols were more concentrated in Laper (262.50 mg GAE/g \pm 9.47) and Placo (203.20 mg GAE/g \pm 2.21 ). Noticeable zinc content was found in Laper (13.56 ppm) and Placo (11.40 ppm) against $3.43 \mathrm{ppm}$ in Madhar. The radical scavenging activity by 2,2-diphenyl-1-picryl hydrazyl (DPPH) and antiradical power measurement by ABTS $\left(2,2^{\prime}\right.$ azino bis-3-ethylbenzothiazoline-6-sulphonic acid) assay have showed good activity for Laper $\left(\mathrm{IC}_{50}=7.50 \mu \mathrm{g} / \mathrm{mL}\right)$ and placo $\left(\mathrm{IC}_{50}=8.01 \mu \mathrm{g} / \mathrm{mL}\right)$. The standard antioxidant compound (quercetin) gave an $\mathrm{IC}_{50}=4.00 \mu \mathrm{g} / \mathrm{mL}$. This study suggested that the high content of total flavonoids, total phenols and minerals in these plants could partly justify the therapeutic use of at least two of the three plants.
\end{abstract}

Keywords Antioxidant Activity, Polyphenols, Zinc, Medicinal Plants, Côte d'Ivoire

\section{Introduction}

In recent time, phytomedicines has drawn special attention as therapeutics giving wide range of treatment options against diseases. Sometimes they are more useful than synthetic drugs due to their economic price, less adverse effects and efficacy in multidrug resistant incidences [1-3]. Today, natural antioxidants molecules from plants sources are required [4,5]. Indeed, the polyphenols compounds are widely found in plants which have proven beneficial effects on human health [6]. Their role as natural antioxidants arouses more and more interest for the prevention and the treatment of cancer, inflammatory and cardiovascular diseases [7]. They are also used as additives in agro-alimentary, pharmaceutical and cosmetic industry [4].

Scientific research was developed for extraction, identification and quantification of natural compounds starting from the various sources such as the agricultural and horticultural cultures or the medicinal plants [8]. It is also necessary to add total flavonoids which are natural compounds, almost universal as the vascular plants. They constitute pigments responsible for yellow colorings, orange and red of various plants organs [9]. The properties of the flavonoids best described are their antioxidant activity and their capacity to scavenge the free radicals like their role in anti-inflammatory drug [ 10,11 ] . Likewise, Zinc has been shown to have an antioxidant role in defined chemical systems. Two mechanisms have been elucidated; the protection of sulfhydryl groups against oxidation and the inhibition of the production of reactive oxygens by transition metals. Supraphysiological concentrations of Zinc have antioxidant-like effects in organelle-based systems and isolated cell-based systems in vitro [12]. The concept of which oxygen, molecule essential for life, can lead to significant cellular damage through the formation of active oxygenated derivatives is still badly perceived in the medical environment. However, many epidemiological studies suggested the role of these oxygenated free radicals 
(OFR) in the development of many pathological processes associated with the atherosclerosis, cancerogenesis and malaria $[13,14]$.To protect itself from the toxic effects of oxygen, the body organism developed antioxidant systems of defense composed of enzymes (glutathion peroxidase), vitamins (A, C, E), trace elements (selenium, zinc) and proteins (ferritin).

Lipoperoxidation is the most accessible aspect of oxidative stress [15]; It is also the most evoked part currently in physiopathology. Several in vitro studies [16,17], in vivo [18] and somewhat in humans [19] were done for the evaluation of the evolution of oxidative stress during malaria [20]. They showed that during the course of the disease, there was an increase in lipoperoxidation measured by malondialdehydes (MDA) and a decrease in the antioxidant system $[21,22]$. To overcome this physiological imbalance, exploration of new sources of natural antioxidants is necessary in view of the potential toxicological risks of synthetic antioxidants. This work is part of the research and development of natural bioactive substances, focused on three plants of the Ivorian pharmacopoeia. Cochlospermum planchonii, Pericopsis laxiflora and Harungana madagascariensis, traditionally used to treat malaria in Côte d'Ivoire and in the West African region [23,24]. The main objective of this study was to evaluate the in vitro antioxidant activity of three medicinal plants by the DPPH free radical scavenging effect and antiradical power by ABTS assay and determine the content of total polyphenols, total flavonoids and zinc, well known for their antioxidant activity.

\section{Materials and Methods}

\subsection{Plant Material}

The plant material consisted of barks of Pericopsis laxiflora (Laper) and Harungana madagascariensis (Madhar) and leaves of Cochlospermum planchonii, (Placo), collected in the locality of Moronou about $20 \mathrm{~km}$ from Toumodi central region of Côte.d'ivoire, between July and September 2014 [24].They were washed and dried under the shade, the fine powder of drug was obtained after crushing using a mechanical crusher (Retsh, M26951).

\subsection{Chemical Reagents}

The reagents used were the DPPH $(2,2$ diphenyl-1-picryl - hydrazyl), Folin-Ciocalteu reagent, ascorbic acid, gallic acid, $\mathrm{AlCl}_{3}$ (aluminiumtrichloride), quercetin. All these products were obtained from Sigma and the solvent used was methanol.

\subsection{Methods}

\subsubsection{Aqueous Extraction}

$100 \mathrm{~g}$ of drug was homogenized in $1 \mathrm{~L}$ of water. After two cycles of homogenization for $5 \mathrm{mn}$, the homogenized was collected in a square clean fabric and was pressed with the hand by application of strong pressures. The solution collected was filtered twice on absorbent cotton then on Whatmann 3 paper then the solution obtained was dried in a drying oven of the type Heraeus ${ }^{\circledR}$ at the temperature of $50^{\circ} \mathrm{C}$ for three days [25].

\subsubsection{Methanolic Extraction}

$50 \mathrm{~g}$ of drug powder were homogenized in $1.5 \mathrm{~L}$ of pure methanol in a mixer; the following steps were identical to those of the aqueous extraction above [26].

\subsubsection{In Vitro Evaluation of the Antioxidant Activity}

\subsubsection{Determination of Total Phenol by} Spectrophotometrically

Method of Wood et al., (2002) [27] was used for the measurement of total polyphenols. A volume of $2.5 \mathrm{~mL}$ of diluted Folin-Ciocalteu reagent FCR (1/10) was added to 30 $\mu \mathrm{L}$ of extract. The mixture was maintained for 2 minutes in the dark at room temperature and $2 \mathrm{ml}$ of calcium carbonate solution $(75 \mathrm{~g} / \mathrm{L})$ was added. Then the mixture was placed for 15 minutes in a water bath at $50^{\circ} \mathrm{C}$, and then cooled quickly. The absorbance was measured at $760 \mathrm{~nm}$ using a spectrophotometer and the polyphenol concentration expressed in milligram of gallic acid equivalent per gram of extract (mg GAE /g).

\subsubsection{Determination of total Flavonoids by} Spectrophotometrically

Method of Marinova and al., (2005) [28] was used for the measurement of the total flavonoïdes. In a flask of $25 \mathrm{ml}$, $0.75 \mathrm{ml}$ of sodium nitrite $\left(\mathrm{NaNO}_{2}\right)$ of $5 \%(\mathrm{~m} / \mathrm{v})$ was added to $2.5 \mathrm{ml}$ of extract. The mixture was added to $0.75 \mathrm{ml}$ of aluminium chloride $\left(\mathrm{AlCl}_{3}\right)$ of $10 \%(\mathrm{~m} / \mathrm{v})$, and then incubated in the dark for 6 minutes. After incubation, $5 \mathrm{~mL}$ of sodium hydroxide solution $(\mathrm{NaOH} 1 \mathrm{~N})$ were added then volume was supplemented to $25 \mathrm{~mL}$. The absorbance was read at $510 \mathrm{~nm}$ and the flavonoid concentration expressed in milligrams of quercetin equivalent per grams of extract (mg $\mathrm{QE} / \mathrm{g}$ ) was determined using a calibration line established in the same conditions.

\subsubsection{Evaluation of DPPH Radical Scavenging Activity}

The evaluation of the anti-oxidant activity of the plant extract was performed using the 2.2-diphényl-1-picryl-hydrazyl (DPPH) radical scavenging assay according to the method of Parejo et al., (2000) [29] with some modifications) range of concentrations (0-200 $\mu \mathrm{g} / \mathrm{mL}$ of extract and Quercetin (antioxidant molecule of reference) was prepared in the ethanol / eau $(70 / 30)(\mathrm{v} / \mathrm{v})$. A volume of $100 \mu \mathrm{L}$ of this solution, was mixed with $3.9 \mathrm{ml}$ of DPPH $(70 \mu \mathrm{M})$ prepared in methanol. After homogenization, the mixture was incubated at the room temperature $\left(25^{\circ} \mathrm{C}\right)$ in the dark. After 15 minutes of incubation the absorbance was read at $517 \mathrm{~nm}$ and the $1 \mathrm{C}_{50}$ which is the Quercetin 
concentration responsible for $50 \%$ of inhibition of DPPH radicals, was determined by projection from $50 \%$ on the graph representing the percentage of inhibition of the DPPH according to the concentrations of the extracts and Quercetin.

\subsubsection{Measurement of Antioxidant Activity by Reduction of ABTS +}

This method was based on the ability of the extracts to scavenge the $\mathrm{ABTS}^{+}$radical cation (2, 2' azino bis-3-ethylbenzothiazoline-6-sulphonic acid). The test was carried out according to the method described by Choong et al., (2007) [30]. The reduction of $\mathrm{ABTS}^{+}$was produced by reaction of $8 \mathrm{mM}$ ABTS $(87.7 \mathrm{mg}$ in $20 \mathrm{~mL}$ of distilled water) and $3 \mathrm{mM}$ of potassium peroxodisulphate $\left(\mathrm{K}_{2} \mathrm{~S}_{2} \mathrm{O}_{8}\right)(0.0162$ $\mathrm{g}$ in $20 \mathrm{ml}$ distilled water) in a ratio $1: 1(\mathrm{v} / \mathrm{v})$. The mixture was then incubated in the dark at room temperature for 12-16 hours. This solution of $\mathrm{ABTS}^{+}$was diluted with methanol to obtain a solution whose absorbance value was $0.7 \pm 0.02$ which was read at $734 \mathrm{~nm}$. Thus, a test specimen of $3.9 \mathrm{ml}$ of this diluted solution of $\mathrm{ABTS}^{+}$was added to $100 \mu \mathrm{L}$ of the compound to test. After Agitation, the mixture was incubated for 6 minutes in the dark $\left(\mathrm{T}=30 \pm 2^{\circ} \mathrm{C}\right)$. The addition of antioxidant reduces the radical and causes the discoloration of the mixture. This discoloration of the radical measured by spectrophotometry at $734 \mathrm{~nm}$ is proportional to the concentration of antioxidants expressed in $\mu \mathrm{mol}$ of Trolox equivalent of antioxidants activity per liter of extract ( $\mu \mathrm{mol} \mathrm{TE} / \mathrm{L})$.

\subsection{Measurement of Zinc Content}

The zinc content was measured by atomic absorption spectrometry [31].

\subsection{Statistical Analysis}

The data were analyzed using Graph Pad PRISM 5 software (Microsoft, USA). The average value accompanied by the standard error (mean $\pm \mathrm{SD}$ ). The difference between two values was considered to be significant when $\mathrm{P}<0.05$. The statistical analysis of the results was carried out using ANOVA followed by the test of Tukey for the multiple comparisons and the determination of the degree of significance.

\section{Results}

\subsection{Total Polyphenols Content}

Figure 1 showed the contents of total phenols that measured by Folin-Ciocalteu reagent in terms of gallic acid equivalent (mg GAE/g). Total phenols varied from 109.20 $\pm 2.21 \mathrm{mg} \mathrm{GAE} / \mathrm{g}$ to $262.50 \pm 9.47 \mathrm{mg} \mathrm{GAE} / \mathrm{g}$ in the extracts. Laper with total phenol contents $262.50 \pm 9.47 \mathrm{mg} \mathrm{GAE} / \mathrm{g}$ had the highest amount in this study followed Placo
$(203 \pm 2.21 \mathrm{mg} \mathrm{GAE} / \mathrm{g})$ and madhar $(109.20 \pm 2.21 \mathrm{mg}$ GAE/g). The results obtained in Placo and Laper are not statistically different ( $p>0.05$ ). Madhar has a relatively lower value compared to the other two plants.

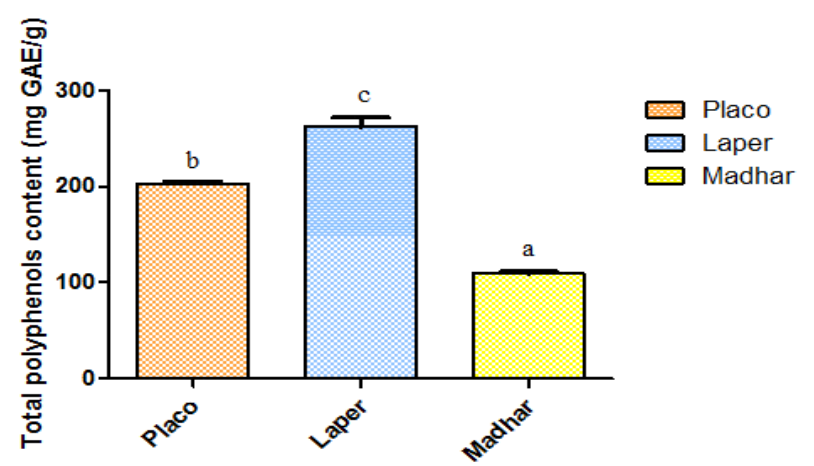

Figure 1. Total polyphenols contents of the extracts of plants (Mean \pm $\mathrm{SD}$ of three trials).

\subsection{Total Flavonoids Content}

Flavonoids contents of the extracts in term of quercetin equivalent (mg QE/g) were between $314.20 \pm 4.41 \mathrm{mg} \mathrm{QE} / \mathrm{g}$ to $560.80 \pm 7.40 \mathrm{mg} \mathrm{QE} / \mathrm{g}$ (Figure 2). The flavonoid content in extract of Laper $(560.80 \pm 7.40 \mathrm{mg} \mathrm{QE} / \mathrm{g})$ was higher than extracts of Madhar $(352.50 \pm 9.46 \mathrm{mg} \mathrm{QE} / \mathrm{g})$ and Placo $(314.20 \pm 4.41 \mathrm{mg} \mathrm{QE} / \mathrm{g})$. A peak value in flavonoids content was obtained with Laper but the results obtained in Placo and Madhar are also important and are not statistically different $(\mathrm{p}>0.05)$.

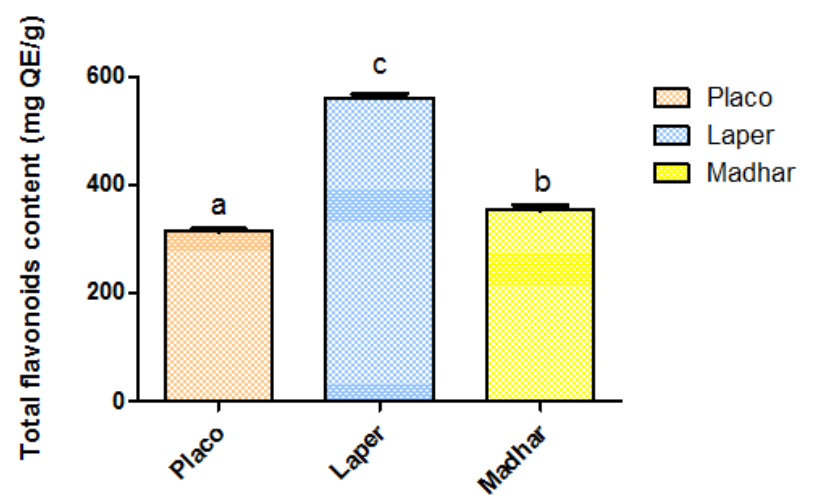

Figure 2. Total flavonoids content of the plants extracts (Mean $\pm \mathrm{SD}$ of three trials).

\subsection{Measurement of Antioxidant Activity}

The different extract showed dose dependent DPPH radical scavenging activity. These results show amount of each extract needed for $50 \%$ inhibition $\left(\mathrm{IC}_{50}\right)$. $\mathrm{IC}_{50}$ of the standard compound (Quercetin) was The anti-oxidant activity was measured by the method of the ability of the extract to scavenge DPPH (2, 2'-diphenyl -1-picrylhydrazyle) radical. $\mathrm{IC}_{50}$ of the standard compound (quercetin) was $4.00 \mu \mathrm{g} / \mathrm{mL}$. The difference between 
quercetin and others is significant $(\mathrm{p}<0.001)$. But the radical scavenging activities of plant extracts are also important and decrease in following Laper $(7.50 \mu \mathrm{g} / \mathrm{mL})$, Placo $(8.01$ $\mu \mathrm{g} / \mathrm{mL})$ and madhar $(147 \mu \mathrm{g} / \mathrm{mL})$.

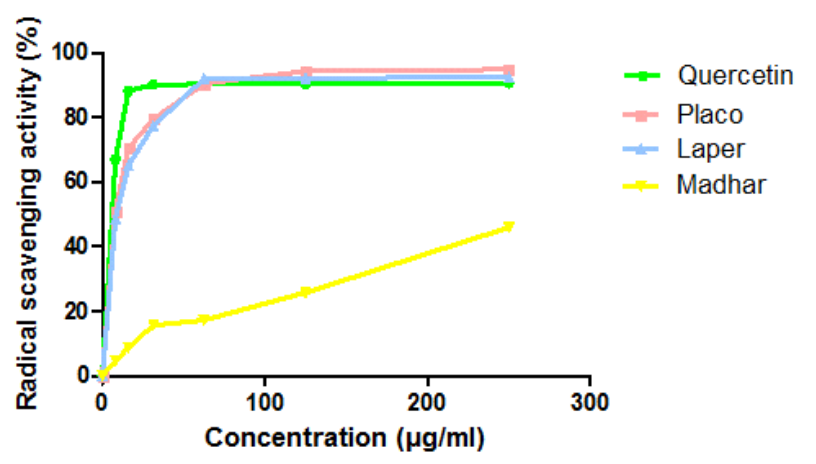

Figure 3. Antiradical activity of the extracts by scavenging of DPPH

\subsection{Inhibiting Capacity of ABTS++ Radical}

Reduction in ABTS radical was also used for measuring the antioxidant activity of the extracts. This method was based on the capacity of the compounds to reduce ABTS radical. The antioxidant activity was measured by inhibition of $\mathrm{ABTS}^{++}$radical obtained starting from the ABTS (ammonium salt of the 2, 2' azino-bis -3-ethylbenzothiazoline -6- sulphonic acid) compared to a reference antioxidant. Trolox (acid 6 hydroxy-2, 5, 7,8tetramethylchroman -2-carboxylic), of which the cyclic molecular structure is similar to that of the vitamin E. So the antioxidant capacity in Trolox equivalent corresponds to the concentration of Trolox ( $\mu \mathrm{mol} \mathrm{T} \mathrm{E} / \mathrm{L}$ ) having the same activity as the same unit concentration of the studied extract. Thus, two plants had an antioxidant activity: Laper $(44.26 \pm 1.63 \mu \mathrm{mol}$ Trolox E /L) and Placo $(43.00 \pm 2.01 \mu \mathrm{mol}$ Trolox E /L) (Figure 4). On the other hand, Madhar had a weak antioxidant activity $(10.29 \pm 0.14 \mu \mathrm{mol}$ Trolox E /L).

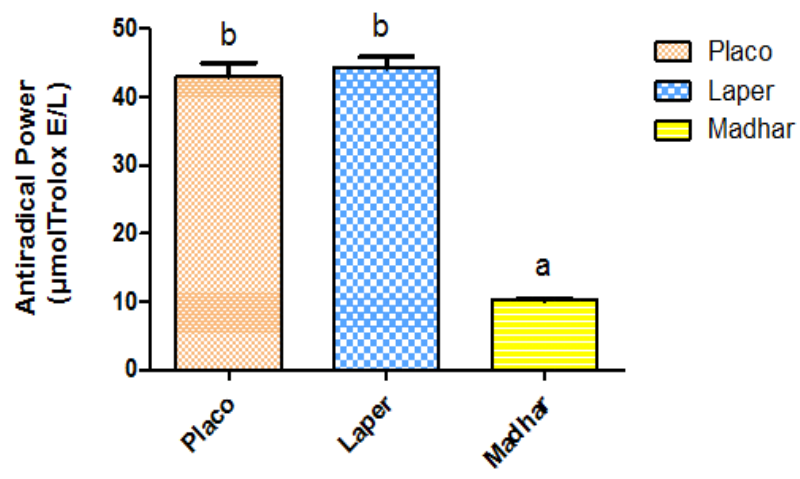

Figure 4. Activity of the extracts by reduction of the ABTS (Mean \pm SD of three trials)

\subsection{Zinc Content}

Measurement of zinc content by atomic absorption spectrometry made it possible to note a good concentration level in Laper with $13.56 \pm 0.97 \mathrm{ppm}$ and Placo $11.40 \pm 0.53$ ppm against 3.43 $\pm 0.32 \mathrm{ppm}$ in Madhar (Figure 5).

It arises from the analysis of these data that Laper has at the same time a good polyphenol content, total flavonoids and zinc. It is followed in the order by Placo and Madhar regarding content of the same compounds.

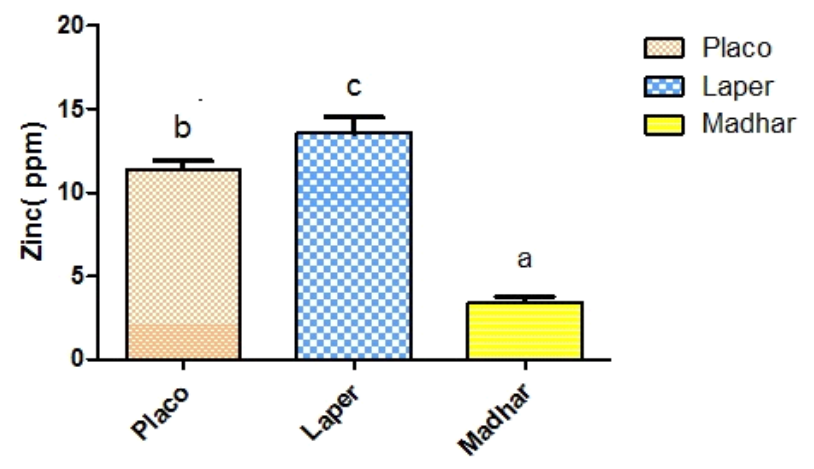

Figure 5. Zinc content of the plants extracts (Mean $\pm \mathrm{SD}$ of three trials).

\section{Discussion}

DPPH radical scavenging method is standard procedure applied to evaluation of antiradical activity. This method is easy, rapid and sensitive way to survey the antioxidant activity of a specific compound or plant extracts [32]. DPPH free radicals, which are stable in methanol shows maximum a proton donating substances such as antioxidant. Radicals would be scavenged and absorbed. The different extracts showed dose dependent DPPH radical scavenging activity. $\mathrm{IC}_{50}$ of the standard compound (Quercetin) was $4.00 \mu \mathrm{g} / \mathrm{mL}$, which is the highest radical scavenging activity. It is similar to the one found by Bidié et al. (2010) [33] with quercetin $\left(\mathrm{IC}_{50}=2 \mu \mathrm{g} / \mathrm{mL}\right)$. The difference between quercetin and the others is significant. But the radical scavenging activity in the plant extracts is also important and decreased in the following order: Laper $\left(\mathrm{IC}_{50}=7.5 \mu \mathrm{g} / \mathrm{mL}\right)>$ Placo $\left(\mathrm{IC}_{50}=\right.$ $8.01 \mu \mathrm{g} / \mathrm{mL})>$ Madhar $\left(\mathrm{IC}_{50}=147 \mu \mathrm{g} / \mathrm{mL}\right)$. Results in Laper and Placo did not differ significantly $(\mathrm{P}>0.05)$. These results are similar to those obtained by Bidie et al. (2010) [33]. Indeed, these authors found an $\mathrm{IC}_{50}$ of $7.5 \mu \mathrm{g} / \mathrm{mL}$ and 10.5 $\mu \mathrm{g} / \mathrm{mL}$ in the extracts of Trichilia prieuriana and Mitragyna ciliata respectively. Their study showed that both plants had very good antioxidant activity due to their high polyphenols and flavonoids content.An antioxidant is defined like a substance which, added at a lower dose with a naturally oxidable product with the air, is able to slow down or to inhibit the phenomenon of oxidation.

This definition can be extended to all the substances which protect the body systems against the potential noxious effects of the processes or reactions which generate an excessive oxidation [34]. Thus, several substances acting as antioxidants in vivo were selected. They include $\beta$-carotene, albumin, uric acid, oestrogens, polyamines, flavonoids, 
ascorbic acid, vitamin E, phenolic compounds, the flavonoïds, zinc and selenium [6]. In this study we studied the correlation between the flavonoïds, total polyphenols and zinc content and the antiradical capacity of three extracts of plant used in traditional medicine to treat malaria $[35,36]$. Therefore, it was observed a strong correlation between the antiradical activity and the simultaneous presence of the three compounds which are the polyphenols, total flavonoïds and zinc. On the other hand, Madhar which contains a relatively low concentration of polyphenols and zinc has a relatively very poor free radical scavenging activity $\left(\mathrm{IC}_{50}>\right.$ $100 \mu \mathrm{g} / \mathrm{mL}$ ). The higher polyphenols concentration observed in laper and placo could be very interesting because the polyphenolic compounds are used more and more in therapeutic [37]. In addition, N'guessan et al. (2007) [38] showed the existence of a correlation between the total phenols content and the free radical scavenging activity. Zinc is essential for human development and function. It provides conformational stability to numerous metalloenzymes. Zinc deficiency is associated with oxidative damage in numerous diseases, including cancer, cirrhosis, coronary artery disease, diabetes and some skin disorders. Abundant evidence demonstrates the antioxidant role for zinc [39]. These investigations provide a comprehensive profile of the antioxidant activity of plant extracts with respect to their phenols and flavonoids content. Many reports of natural antioxidants of plants have been published and their importance in health, food and preventive medicine has been well documented [40, 41]. The abundance of polyphenol and flavonoids compounds would confirm the therapeutic properties that there assigned in ethnotherapy.

\section{Conclusions}

The plants studied have a good total polyphenols, total flavonoids and zinc contents. Laper and Placo are sure to have antioxidant activity, unlike Madhar whose antioxidant activity has not been demonstrated. At the end of this work, we noted that medicinal plants concentrate in their tissues chemical substances, such as those mentioned above, which formed the basis of their pharmacological properties. In line of this, Laper and Placo could be potential sources of natural antioxidants.

\section{Acknowledgements}

Our sincere thanks go to the entire staff of the Institut National Polytechnic Houphouët-Boigny (INP-HB) of Yamoussoukro for the analysis of the physicochemical compounds of the plants extracts. We are also grateful to the traditional healers of the village of Moronou in the city of Toumodi for their collaboration.

\section{REFERENCES}

[1] T. Ohba, Y. Yoshino, M. Ishisaka, N. Abe, K. Tsuruma, M. Shimazawa, M. Oyama, T. Tabira, H. Hara. Japanese Huperzia serrata extract and the constituent, huperzine A, ameliorate the scopolamine-induced cognitive impairment in mice. Bioscience, Biotechnology and Biochemistry; 79:1838-44, 2015.

[2] M.N. Uddin, R. Afrin, M.J. Uddin, A.H.M.K. Alam, Rahman, A.A. Sadik G. Vanda roxburghii chloroform extract as a potential source of polyphenols with antioxidant and cholinesterase inhibitory activities: Identification of a strong phenolic antioxidant. BMC Complementary and Alternative Medecine; 15:195, 2015.

[3] M. Ye, J. Moon, J. Yang, H.H. Lim, S.B. Hong, I. Shim, H. Bae. The standardized Lycium Chinense fruit extract protects against Alzheimer's disease in 3xTg-AD mice. Journal of Ethnopharmacology; 172:85-90, 2015.

[4] M.Suhaj. Spice antioxidants isolation and their antiradical activity: a review. Journal of Food Composition and Analysis; $19531-537,2006$

[5] M.B. Tadhani, V.H.Patel, and R. Subhash. In vitro antioxidant activities of Stevia re-baudiana leaves and callus. Journal of Food Composition and Analysis; 20:323-329, 2007.

[6] C. Koechlin-Ramonatxo. Oxygen, oxidative stress and antioxidant supplementation, or another way for nutrition in respiratory diseases. Nutrition and Clinical Metabolism; 20(4): 165-77, 2006.

[7] D.I.Vârban, M. Duda, R.Vârban, and S.Muntean. Research Concerning the Organic Technology for Satureja Hortensis L. Culture. Bulletin UASVM Agriculture. 66 (2) 225-229, 2009.

[8] D. Huang, B. Ou and R.L. Prior. The chemistry behind antioxidant capacity assays. Journal of Agriculture and Food Chemistry; 53:1841-1856, 2005.

[9] B.T. Havsteen. The biochemistry and medical significance of the flavonoids. Pharmacology and Therapeutics 96; 67-202, 2002.

[10] D. Atmani , N. Chaher, D. Atmani, M. Berboucha, N. Debbache and H. Boudaoud. Flavonoids in Human Health: From Structure to Biological Activity. Current Nutrition and Food Science; 5, 225-237, 2009

[11] P. Strzyga-Łach and H. Czeczot. The role of flavonoids in the modulation of inflammation. Pol Merkur Lekarski; 40 (236):134-40, 2016

[12] T.M. Bray, W.J. Bettger. The physiological role of zinc as an antioxidant. Free Radical Biology and Medicine; 8 (3): 281-291, 1990.

[13] K. Becker , L.Tilley, J.L.Vennerstrom , D. Robetrs, D. Rogerson and H. Ginburg . Oxidative stress in malaria parasite-infected erythrocytes: host-parasite interaction. International Journal of Parasitology; 34, 163-189, 2004.

[14] N. Narsaria, C. Mohanty, B.K. Das, S.P. Mishra and R. Praosad. Oxidative stress in children with severe malaria; Journal of Tropical Pediatrics, 58:1-4, 2011.

[15] E. Schwarzer, P. Arese, and O.A. Skorokhod. Role of the Lipoperoxidation Product 4-Hydroxynonenal in the Pathogenesis of Severe Malaria Anemia and Malaria 
Immunodepression. Oxidative Medecine and Cellular Longevity; 638416, 2015.

[16] O.A. Skorokhod,L. Caione ,T. Marrocco, G. Migliardi, V. Berrera, P. Arese , W. Piacibello and Z. Schwarzer. Inhibitionof erythropoiesis in malaria anemia: role of hemozoin and hemozoin-generated 4-hydroxynonenal. Blood; 116: 4328-4337, 2010.

[17] S. Uyoga, O.A. Skorokhod, M. Opiyo, E.N. Orori, T.N. Williams, P. Arese and E. Schwarzer. Transfer of 4-hydroxynonenal from parasitized to non-parasitized erythrocytes in rosettes. Poposed role in severe malaria anemia. British Journal of Haematology; 157, 115-124, 2012.

[18] O.I. Iribhogbe, E.O. Agbaje, I.A. Oreagba, O.O. Aina and A.D. Ota. Oxidative stress and micronutrient therapy in malaria: an in vivo study in Plasmodium berghei infected mice. Pakistan Jouranl of Biology Sciences; 16(4):160-7, 2013.

[19] A.G. Kulkarni, A.N. Suryakar, A.S. Sardeshmukh and D.B. Rathi. Studies on biochemical changes with special reference to oxidant ant antioxidants in malaria patients. Indian Journal of Clinical Biochemistry; 18, 136-149, 2003.

[20] R. Aguilar, T. Marrocco, O.A. Skorokhod, A. Barbosa, A. Nhabomba, M.N. Manaca, C. Guivart, L. Quintó, P. Arese, P.L. Alonso, C. Dobaño and E. Schwarzer. Blood oxidative stress markers and Plasmodium falciparum malaria in non-immune African children. British Journal of Haematology; 164(3):438-50, 2014.

[21] M.J. Griffiths, F. Ndungu, K.L. Baird, D.R. Muller, K. Marsh and C. Newton. Oxidative stress and erythrocyte damage in Kenyan children with severe Plasmodium falciparum malaria. British Journal of Haematology; 113 (2): 486-491, 2001.

[22] R. Bilgin, M.S. Yalcin, G.Yucebilgic, and S. Yazar. Oxidative stress in vivax malaria. Korean Journal of Parasitology; 50 (4): 375-377, 2012.

[23] M.S. Traoré, M.A. Baldé, M.S Diallo, E.S. Baldé, S. Diané, A. Camara, A. Diallo, A. Balde, A. Keïta, S.M. Keita, K. Oularé, F.B. Magassouba, I. Diakité, A. Diallo and 1. Pieters L. Ethnobotanical survey on medicinal plants used by Guinean traditional healers in the treatment of malaria. Journal of Ethnopharmacology; 150 (3): 1145- 53, 2013.

[24] K.B. Bla, J.N.D. Trébissou, A.P. bidié, Y.J. Assi, N. Zirihi-Guédé and A. J. Djaman . Etude ethnopharmacologique des plantes antipaludiques utilisées chez les Baoulé-N'gban de Toumodi dans le Centre de la Côte d'Ivoire. Journal Apllied of Biosciences ; 85 :7775-7783, 2015.

[25] G.N. Zirihi, A.M. Kra, C. Bahi and F. Guedé-Guina. Critères de sélection, techniques rapides d'extraction des principles actifs et méthodes d'évaluation de l'activité immunogène. Revue de Medécine et Pharmacopée Africaine, 17 : 131-8, 2003.

[26] A.P. Bidie, E. Koffi , H.F.Yapi, A.A. Yémié, A.J. Djaman. And F. Guede-guina. Evaluations of the toxicity of a methanolic total extract of Mitragyna ciliata a natural antimalaric. International Journal of Biological and Chemical Sciences; 4(5): 1509-1518, 2010.

[27] J. E.Wood, Senthilmohan and A.V. Peskin. Antioxidant activity of procyanidin-containing plant extracts at different pH. Food Chemistry, T.77. 155-161., 2002.

[28] D. Marinova, F. Ribarova and Atanassova. Total phenolics Bulgarian fruits and vegeta-bles. Journal of the University of Chemical Technology and Metallurgy, 40 (3): 255-260, 2005.

[29] L. Parejo , C. Codina ,C. Petrakis and P.Kefalas. Evaluation of scavenging activity assessed by $\mathrm{Co}$ (II)/EDTA-induced luminal chemilunes-cence and DPPH (2,2-diphényl-1-pycryl-hydrazyl) free radical assay. J PharmacolToxicol Method, 44: 507-512., 2000.

[30] C. Choong, T.T.Van-Den , F. Roger and M.C.F. L. Roger. Antioxidant activities, phenolic and beta-carotene contents of sweet potato genotypes with varying flesh colours. Food Chemistry; 103 (3): 829-838., 2007.

[31] F. Shahidi, U.D. Chavan, A.K. Bal and D.B. Mckenzie. Chemical Composition of Beach pea (Lathyrusmaritimus L). Plant parts. Food Chemistry; 64: 39-44, 1999.

[32] I.I. Koleva, T.A.Van Beek, J.P.H. Linssen, A. De Groot, L.N. Evstatieva. Screening of plant extracts for antioxidant activity: a comparative study on three testing methods. Phytochemical Analysis 13: 8-17, (2002).

[33] A.P. Bidie, B. N'guessan, A.F.YAPO, J.D. N'guessan and J. Djaman. Sciences Nature; 8: 1-11, 2011.

[34] H. Shimizu. Relationship between plasma glutathione levels and cardiovascular disease in a defined population: the Hisayama study, Stroke 35 (9): 2072-2077, 2004.

[35] A. Lamien-Meda , M. Kiendrebeogo, M. Compaoré, R.N. Meda, M. Bacher, K. Koenig, T. Pacher, H.P Fuehrer, H. Noedl, M. Willcox and J. Novak. Quality assessment and antiplasmodial activity of West African Cochlospermum species. Phytochemistry; 119: 51-61, 2015.

[36] DF. Malan, D.F. Neuba, K.L. Kouakou. Medicinal plants and traditional healing practices in Ehotile people, around the Aby Lagoon (eastern littoral of Côte d'Ivoire) Journal of Ethnobiology and Ethnomedecine; DOI 10.1186/s13002-015-0004-8, 2015.

[37] A. Crozier, D. Del Rio, M.N. Clifford. Bioavailability of dietary flavonoids and phenolic compounds. Molecular Aspects of Medicine; 31: 446-467, 2010

[38] J.D. N'guessan, G.N. Zirihi, A.K.M. Kra, K. Kouakou, A.J. Djaman and F. Guede-Guina. Free radical scavenging activity, flavonoid and phenolic contents of selected Ivoirian plants. International Journal of Natural and Applied Sciences; 4: 425-429., 2007.

[39] M.M. Pandey , S. Khatoon , S. Rastogi, A.K. Rawat . Determination of flavonoids, polyphenols and antioxidant activity of Tephrosia purpurea: a seasonal study. Journal of Integrative Medecine; 14 (6): 447-455, 2016.

[40] B. Halliwell, J. Rafter, A. Jenner. Health promotion by flavonoids, tocopherols, tocotrienols, and other phenols: direct or indirect effects? Antioxidant or not? The American Journal of Clinical Nutrition; 81: 268S - 76S, 2005.

[41] S.M. Patil, V.J. Kadam, R. Ghosh. In vitro antioxidant activity of methanolic extract of stem bark of Gmelina arborea Roxb. (Verbenaceae), International Journal of PharmTech Research; 1:1480- 1484, 2009. 